\title{
Deacidification of High Free Fatty Acid- Containing Rice Bran Oil by Non-conventional Reesterification Process
}

\author{
Sibban Singh ${ }^{1 *}$ and R.P. Singh ${ }^{2}$ \\ ${ }^{1}$ Department of Ind. Chem. (Oils, Fats \& Waxes), ISTAR (Vallabh Vidyanagar, INDIA) \\ ${ }^{2}$ H.B. Technological Institute (Kanpur-208002, INDIA)
}

\begin{abstract}
Rice bran (Oryza sativa) oil is known for containing higher amount of free fatty acid (FFA) generated by hydrolytic enzyme. This FFA causes heavy neutral oil losses due to saponification and emulsification since it produces large amount of soap in the conventional alkali refining process. In the present study the FFA of degummed rice bran oil (RBO) was significantly reduced by reesterifying it with glycerol. The reesterification process was carried out by varying the temperature and amount of excess glycerol using $0.2 \%$ catalyst $\left(\mathrm{SnCl}_{2}\right)$. The maximum efficiency of the process could be attained at $200^{\circ} \mathrm{C}$ using $70 \%$ excess glycerol and the maximum reduction in acid value (from 24.3 to 3.0) of RBO was observed within $4 \mathrm{~h}$. The reesterified RBO was used to prepare stand oil and varnish and their performance characteristics were compared with those of the products obtained from dehydrated castor oil (DCO).
\end{abstract}

Key words: FFA, RBO, reesterification, stannous chloride, DCO, stand oil, varnish

\section{INTRODUCTION}

Rice bran oil $(\mathrm{RBO})^{1)}$ can play a very important role towards health benefits particularly for lowering of LDL cholesterol. But utilization of this oil has remained a problem that higher amounts of free fatty acid (FFA) generated by naturally occurring hydrolytic enzymes may give off-flavor. The FFA is removed as soap-stock in the conventional alkali refining process. But in this process the neutral oil losses ${ }^{2)}$ are considerably high due to alkali refining as part of vegetable is also saponified in the process besides neutralization of free fatty acid. Chemical refining of oil with alkali produces large quantity of effluent. In order to avoid these problems, various non-conventional methods to remove the FFA from rice bran oil have been tried in the past : solvent extraction ${ }^{3)}$, steam distillation ${ }^{4)}$, alkali neutralization of miscella ${ }^{5}$ and reesterifying back to glycerides with the help of glycerol ${ }^{6}$. However, these processes were not completely free from the problems and limitations when applied on commercial scale. Therefore, in the present study on reesterification, we have tried to get more techno-economically feasible process conditions.

\section{MATERIALS AND METHODS}

\subsection{Materials}

The experimental sample of degummed rice bran oil (DRBD) was procured from M/s Ashwin Vanaspati pvt. Ltd., Samlaya, Gujarat (India). Rosin modified phenolic resin (Bluebell Polymers Pvt. Ltd., Ahmedabad) and dehydrated castor oil (DCO) were obtained from M/s Kanak Oil Mills Pvt. Ltd. (Anand). Glycerol (Chiti-Chem. Corporation, Baroda), catalyst?stannous chloride (S.D. Fine Chemical, Ltd, Bombay), and other chemicals used were of analytical grade. Nitrogen gas was supplied by Sophisticated Instrumentation Centre for Applied Research and Testing (SICART), Vallabh Vidyanagar.

\subsection{Methods}

\subsubsection{Analysis}

The DRBO and DCO were first analyzed for specific gravity, acid value, saponification value, iodine value, peroxide value, referactive index, colour, viscosity and unsaponifiable matter using standard methods ${ }^{7,8}$.

2.2.2 Reesterification of high FFA rice bran oil

The reesterification of DRBO was carried out with dif-

*Correspondence to: Sibban Singh, Department of Ind. Chem. (Oils, Fats \& Waxes), ISTAR, Vallabh Vidyanagar, INDIA E-mail: sibban_singh@yahoo.co.in Accepted September 29, 2008 (received for review August 8, 2008)

Journal of Oleo Science ISSN 1345-8957 print / ISSN 1347-3352 online

http://www.jstage.jst.go.jp/browse/jos/ 


\section{S. Singh and R.P. Singh}

ferent amozunts of the DRBO, glycerol and catalyst $\mathrm{SnCl}_{2}$ in three neck flask having $500 \mathrm{~mL}$ capacity equipped with thermometer pocket, stirrer and provision for passing $\mathrm{N}_{2}$ gas. The mixture was continuously agitated for about 6 to 7 $\mathrm{h}$ at set temperature under the atmosphere of $\mathrm{N}_{2}$ gas bubbling through the reaction mass at $50 \mathrm{~mL} / \mathrm{min}$. In order to monitor the reduction in FFA, the samples were drawn out at $1 \mathrm{~h}$-interval and then analyzed for acid value by titrating with an alcoholic potassium hydroxide solution. Further, the amount of excess glycerol was increased and its effect on reaction rate was examined by carrying out the same experiment as described above.

2.2.3 Preparation of stand oil from reesterified rice bran oil (RRBO) and its application in varnish formulation

One hundred grams of RRBO and $0.5 \%$ lead acetate catalyst was taken and the mixture was heated slowly to raise the temperature up to $250-260^{\circ} \mathrm{C}$ under constant agitation. The viscosity, as a tool to monitor the reaction, was measured after every hour. The process was continued till no appreciable change was observed in viscosity. The stand oil thus prepared was mixed with $20 \%(\mathrm{w} / \mathrm{w})$ rosin modified phenolic resin for application as varnish. The process was repeated with DCO taken as standard for evaluation of the performance characteristics. All products prepared as mentioned above were applied on metallic panels and the coated films were analyzed for their properties related to their performance by standard methods ${ }^{9}$.

\section{RESULTS AND DISCUSSION}

The experimental DRBO used for the reesterification process and DCO sample were analyzed for their physicochemical characteristics and the results are shown in the
Table 1. The acid value of DRDO sample is 24.25. Other characteristics depicted in the table are within the standard values of DRBO and DCO.

The effect of the catalyst dose on reesterification with $50 \%$ excess glycerol was investigated. The reaction was carried out at $150^{\circ} \mathrm{C}, 180^{\circ} \mathrm{C}$ and $200^{\circ} \mathrm{C}$ for $5 \mathrm{~h}$-duration and the results are shown in Table 2. The drop in acid value of $\mathrm{RRBO}$ was the minimum at $0.2 \%$ catalyst concentration, as shown in Table 2. The results clearly indicate that $0.2 \%$ catalyst concentration is the optimum dose for the reduction in FFA present in DRBO.

Further, the reaction was carried out using 50\%-excess glycerol and the acid value was determined each hour. As shown in Fig.1, the rate of reesterification increased with temperature. The maximum drop in acid value was about 7.1 at $150^{\circ} \mathrm{C}$ and 19.3 at $200^{\circ} \mathrm{C}$ for 6 h-duration.

When the percentage of excess glycerol was increased up to $70 \%$, the reesterification rate was faster than the ear-

Table 2 Effect of Catalyst Concentration on Reesterification ${ }^{1}$.

\begin{tabular}{|c|c|c|c|}
\hline \multirow{2}{*}{$\begin{array}{c}\text { Catalyst Conc. } \\
(\mathbf{\%}, \mathbf{w} / \mathbf{v})\end{array}$} & \multicolumn{3}{|c|}{ Drop in Acid Value for $\mathbf{6} \mathbf{~ h .}$} \\
\cline { 2 - 4 } & $\mathbf{1 5 0} \mathbf{\circ}^{\circ} \mathrm{C}$ & $\mathbf{1 8 0}^{\circ} \mathrm{C}$ & $\mathbf{2 0 0}^{\circ} \mathrm{C}$ \\
\hline 0.10 & 5.6 & 8.3 & 17.6 \\
\hline 0.15 & 6.2 & 9.1 & 18.2 \\
\hline 0.20 & 7.0 & 10.7 & 19.3 \\
\hline 0.25 & 6.7 & 10.3 & 19.2 \\
\hline 0.30 & 6.3 & 10.0 & 19.0 \\
\hline
\end{tabular}

$1: 50 \%$ excess glycerol was used

Table 1 Physicochemical Characteristics ${ }^{1}$ of the Experimental Rice Bran Oil and Dehydrated Castor Oil.

\begin{tabular}{|l|c|c|}
\hline CHARACTERISTICS & RICE BRAN OIL & DEHYDRATED CASTOR OIL \\
\hline Specific gravity $\left(\mathbf{3 0}^{\circ} \mathrm{C} / \mathbf{3 0}^{\circ} \mathrm{C}\right)$ & 0.920 & 0.9238 \\
\hline Acid value & 24.3 & 4.5 \\
\hline Saponification value & 189.4 & 192.6 \\
\hline Iodine value & 95.6 & 124.2 \\
\hline Peroxide value & 3.2 & 2.6 \\
\hline Refractive index & 1.4670 & 1.4802 \\
\hline Color value (lovibond tintometer, $1 / 4$ " cell) & 42.1 & 6.0 \\
\hline Unsaponifiable matter (\%) & 4.8 & 0.8 \\
\hline Viscosity at $30^{\circ} \mathrm{C}$ (poise) & - & 3.5 \\
\hline
\end{tabular}

1 : average of two determinations 
lier case (Fig. 2). The maximum reduction in acid value was 20.2 at $200^{\circ} \mathrm{C}$ within $4 \mathrm{~h}$. It was noticeably better than that obtained with $50 \%$-excess glycerol at $200^{\circ} \mathrm{C}$ even after $7 \mathrm{~h}$.

Figure 1 also shows the decrease in acid value during the reesterification process using 100\%-excess glycerol. The results followed the similar trend as mentioned earlier. However, the impact of increasing the amount of glycerol is not encouraging as the maximum drop in acid value is about 20.0 after 5 h i.e. almost same as that when $70 \%$ -

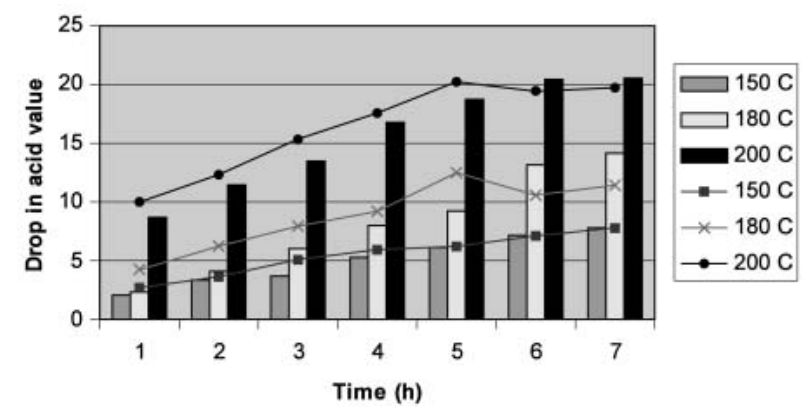

Fig. 1 Reesterification of DRBO with 50\%-Excess Glycerol (denoted by columns ) \& 100\%Excess Glycerol (denoted by lines), Catalyst Concentration was $0.2 \%$. excess glycerol was used.

Therefore, it can be concluded that 70\%-excess glycerol, $0.2 \%$ of catalyst concentration and $200^{\circ} \mathrm{C}$ were the most suitable conditions for the reesterification of high FFAcontaining RBO.

The RRBO was alkali neutralized (acid value $=0.42$ ) and taken for stand oil and varnish preparation and the properties of their coated films were shown in Table 3. Also these results were compared to those obtained from DCO taken as a standard. The drying rate of both products prepared from RRBO i.e. stand oil and its varnish is slightly lower

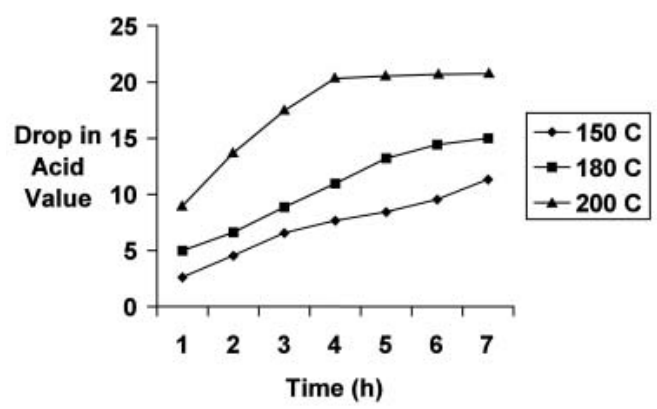

Fig. 2 Reesterification of DRBO with 70\%-Excess Glycerol. Catalyst Concentration was $0.2 \%$.

Table 3 Performance Characteristics of Prepared Stand Oils and Varnishes from RARBO ${ }^{\mathrm{a}}$ and DCO.

\begin{tabular}{|c|c|c|c|c|c|c|c|}
\hline \multirow{2}{*}{ Sr.no } & \multirow{2}{*}{$\begin{array}{l}\text { Stand oil/ } \\
\text { varnishes }\end{array}$} & \multirow{2}{*}{$\begin{array}{c}\text { Viscosity } \\
\text { (poise) }\end{array}$} & \multicolumn{3}{|c|}{ Drying properties $^{\text {b }}(\mathbf{h})$} & \multirow{2}{*}{$\begin{array}{c}\text { Flexibility } \\
1 / 4 " \\
\text { mandrel }\end{array}$} & \multirow{2}{*}{$\begin{array}{c}\text { Scratch } \\
\text { hardness } \\
\text { (kg) }\end{array}$} \\
\hline & & & SD & HD & TFD & & \\
\hline 1. & RRBSO & 10.3 & 2.5 & 9.0 & 16.0 & $\mathrm{p}$ & 1.0 \\
\hline 2. & DCSO & 12.5 & 2.0 & 7.5 & 12.2 & $\mathrm{P}$ & 1.3 \\
\hline 3. & $\begin{array}{l}\text { Varnish from } \\
\text { RARBSO }\end{array}$ & 12.8 & 2.2 & 7.8 & 14.6 & $\mathrm{P}$ & 1.1 \\
\hline 4. & $\begin{array}{l}\text { Varnish from } \\
\text { DCSO }\end{array}$ & 14.0 & 1.8 & 6.5 & 10.6 & $\mathrm{P}$ & 1.5 \\
\hline
\end{tabular}

a - acid value was 0.42

$\mathrm{b}-2 \%$ mixed dryers(Co-octoate, $\mathrm{Pb}$-octoate and $\mathrm{Mn}$-octoate) were used

RARBO — Reesterified and alkali neutralized rice bran oil

RARBSO - Reesterified and alkali neutralized rice bran stand oil

DCO — Dehydrated castor oil

DCSO — Dehydrated castor stand oil

SD - Surface drying

HD — Hard drying

TFD — Tack free drying

$\mathrm{P} \longrightarrow$ Pass 


\section{S. Singh and R.P. Singh}

than the same products obtained from DCO. However, the flexibility and scratch hardness of RRBO's samples are quite comparable to the standard one and therefore, the RRBO can be suitably used as a component in the varnish preparation.

\section{ACKNOWLEDGEMENT}

Authors are grateful to the authorities of ISTAR, Vallabh Vidyanagar and SICART, Vallabh Vidyanagar for providing all the facilities needed from time to time for smooth conduction of the experimental work.

\section{References}

1. Hui, Y.H. Bailey's Industrial Oil \& Fat Products, 2, John Wiley \& Sons, Inc., New York. pp. 399-406 (1996).

2. Swern, D. Bailey's Industrial Oil \& Fat Products, 2, John Wiley \& Sons, Inc., New York. p. 274 (1982).
3. Wada, S.; Koizumi, C.; Nonka, J. Effect of caustic refining, solvent refining and steam refining on the deacidification and colour of high FFA rice bran oil. J. Am. Oil Chem. Soc. 62, 1492-1495 (1985).

4. Forster, A.; Harper, A.J. Physical refining. J. Am. Oil Chem. Soc. 60, 265-271(1983).

5. Bhattacharya, A.C.; Majumdar, S.; Bhattacharya, D.K. Edible quality of rice bran oil from high FFA rice bran oil by miscella refining. J. Am. Oil Chem. Soc. 63, 1189-1191 (1986).

6. Millwalla, R.H.; Shitole, A.D. J. Oil Technol. Assoc. India 19, 70-71 (1978).

7. Official and Tentative Methods of American Oil Chemists' Society (Link, W.E. ed.). $3^{\text {rd }}$ edn. Am. Oil Chem. Soc. Champaign, Illions (1974).

8. Official Methods and Recommendation Practices of the American Oils Chemists' Society (Walker, R.J. ed.). $3^{\text {rd }}$ edn. Am. Oil Chem. Soc. Champaign, Illions (1974).

9. Martin C.R. Technology of Paints, Varnishes and Lacquers, R.E. Krieger Publishing Co., Malabar, Florida, p. 84 (1974). 